\title{
Breeding Tomatoes for Salt Tolerance: Variations in Ion Concentrations Associated with Response to Salinity
}

\author{
Y. Saranga, D. Zamir, A. Marani, and J. Rudich ${ }^{1}$ \\ Department of Field and Vegetable Crops, Faculty of Agriculture, The Hebrew University of Jerusalem, \\ P.O. Box 12, Rehovot 76100, Israel
}

Additional index words. Lycopersicon esculentum, L. pennellii, L. cheesmanii, L. peruvianum, sodium, potassium, chlorine

\begin{abstract}
Accessions of four tomato species, Lycopersicon esculentum Mill. (Le), L. pennellii (Corr.) O'Arey (Lpen), L. cheesmanii Riley $(\mathbf{L c})$, and $L$. peruvianum (L.) Mill., (Lper), and interspecific populations were irrigated with saline water under field conditions and concentrations of $\mathrm{Na}, \mathrm{K}, \mathrm{Cl}, \mathrm{Ca}$, and $\mathrm{Mg}$ in leaves and stems were determined. Potassium : sodium ratios in leaves and stems of salt-tolerant genotypes were higher under salinity and were moderately changed by salinity compared to the sensitive genotypes. In the tolerant wild accessions and $F_{1}(L e \times L p e n)$, Cl concentrations in leaves and the ratio between $\mathrm{Cl}$ in leaves to $\mathrm{Cl}$ in stems were lower than in the sensitive Le cultivar. Regulation of the $\mathrm{K}$ : Na ratio was found in tolerant wild accessions and tolerant Le cultivars, while regulation of $\mathrm{Cl}$ concentration in leaves was found only in the wild germplasm. The effects of ion concentrations on dry matter of interspecific segregating populations, $F_{2}(\operatorname{Le} \times \operatorname{Lpen}$ and $\mathrm{BC}_{1}(\mathrm{Le} \times(\mathrm{Le} \times \operatorname{Lpen}))$, were studied by regression analyses. Dry matter was positively correlated with the $K$ : Na ratio in stems and negatively correlated with the $\mathrm{Cl}$ concentrations in leaves and stems, thus confirming the results obtained by comparison between the tolerant and sensitive accessions.
\end{abstract}

Saline conditions disrupt several physiological processes in plants leading to reduction in growth and yield (Flowers et al., 1977; Greenway and Munns, 1980). Two major strategies characterize the response of plants to salinity: 1) The glycophytic-like mechanism is based on the exclusion of ions from the plant tissue and the use of organic compounds for osmotic adjustment. This mechanism is effective at low and moderate salinity levels. 2) The halophytic-like mechanism is based on the inclusion and compartmentation of ions and their use as osmotic compounds. Most plants employ both strategies in adapting to salt stress (Cheesenam, 1988; Lerner, 1985).

Various modes of salinity tolerance have been found in Lycopersicon. The cultivated tomato Le exhibits the typical glycophytic reaction, with a preferential absorption of $\mathrm{K}$ over $\mathrm{Na}$ (Besford, 1978). At low salinity levels, Na was found only in the roots and in the lower part of the stem; as salinity increased, Na was found further up, and on reaching the leaves it was localizedmainly in the petioles (Besford, 1978; Rush and Epstein, 1981). As in the case of $\mathrm{Na}$, the absorption and translocation of $\mathrm{Cl}$ is also prevented in the cultivated tomato (Phills et al., 1979; Sacher et al., 1983).

In the wild species Lpen, Lper, and $\mathrm{Lc}, \mathrm{Na}$ and $\mathrm{Cl}$ concentrations increased and $\mathrm{K}$ concentrations decreased with salinity (Phills et al., 1979; Rush and Epstein, 1981; Shannon et al., 1987). Concentrations of $\mathrm{Na}$ in the wild species were higher than in Le and the ion was evenly dispersed in all tissues. In Lc, high concentrations of $\mathrm{K}$ were toxic, while similar levels of Na were not (Rush and Epstein, 1981).

We previously described the salt tolerance of various fieldgrown Lycopersicon accessions (Saranga et al., 1991). Variations

Received for publication 9 Sept. 1992. Accepted for publication 24 Oct. 1992. This research was conducted within the framework of the Cooperative Arid Land Agricultural Research-Egypt, United States, Israel (CALAR), funded by the U.S. Agency for International Development (Contract no. NEB-0170-A-00-2047-00) and administered by the San Diego State Univ. Foundation. The cost of publishing this paper was defrayed in part by the payment of page charges. Under postal regulations, this paper therefore must be hereby marked advertisement solely to indicate this fact.

'Deceased May 1986. in salt tolerance were found among tomato cultigens, and Lpen and Lper showed higher tolerance levels than Le and Lc. An interspecific $\mathrm{F}_{1}(\mathrm{Le} \times$ Lpen) exhibited the highest tolerance of all the genotypes examined.

In this paper we report on variations in the ion concentrations of field-grown, salt-tolerant, and salt-sensitive Lycopersicon accessions and segregating populations resulting from a cross between Le and Lpen.

\section{Materials and Methods}

Ambient conditions and management. Four field trials were conducted at the Ramat Negev Experimental Station in the Negev desert in Israel, where various Lycopersicon accessions were examined under saline water irrigation. Monthly means ranged from 10C in April to 20C in August (minimum) and from 25 to $34 \mathrm{C}$ (maximum), and pan evaporation from 7 to $11 \mathrm{~mm} \cdot \mathrm{day}^{-1}$. The soil was sandy loam with volumetric field capacity of $14 \%$ to $15 \%$. Fresh water was applied until anthesis of the first flowers (3 to 4 weeks after transplanting), after which saline water was introduced. All treatments received equal amounts of water, ranging from 400 to $490 \mathrm{~mm}$ per season, applied by drip irrigation. Sodium chlorine and $\mathrm{CaCl}_{2}$ at a molar ratio of $4: 1$, similar to that of the local aquifer, was dissolved in fresh water to achieve the desired salinity. More details of ambient conditions and management were described previously by Saranga et al. (1991).

Le cultigens. Tomato cultivars and breeding lines (denoted hereafter as cultigens) were grown in 1985, irrigated with water having electrical conductivities (ECi) of 1.5 (control), 5, or 10 $\mathrm{dS} \cdot \mathrm{m}^{-1}$, in a split-plot design (salinity in main plots) with nine replications and a single plant per subplot. Two major types of responses were noticed with respect to ion concentrations. Data are accordingly presented here for the control cultivar M82-1-8 (M82) and for Far-77-247-1 (F77), previously characterized as moder-

Abbreviations: ECi, electrical conductivities; Lc, Lycopersicon cheesmanii; Le, Lypopersicon esculentum; Lpen, Lycopersicon pennellii; Lper, Lycopersicon peruvianum; $\mathrm{TD}$, total dry matter. 
ately sensitive and sensitive, respectively, and denoted hereafter as sensitive, and the tolerant cultivars, Bulgaria 12 (B 12) and Mercado (Mer) (Saranga et al., 1991).

Wild species. The control tomato cultivar, M82, and wild Lycopersicon species, Lpen acc. LA-716 (Lpen716), Lc act. LA1401 (Lc1401), and Lper acc. PI-127831 (Lper127831), and the interspecific progeny of M82 $\times$ Lpen716 $\left(\mathrm{F}_{1}\right)$, were examined in three trials conducted in 1984, 1985, and 1986 (excluding Lc1401 and Lper127831). Treatments of Eci $=1.5$ (control), 10, and 20 $\mathrm{dS} \cdot \mathrm{m}_{-1}$ were applied in a split-plot design (salinity in main plots). The experiments of 1984 and 1985 consisted of two replications and five plants per subplot, while the 1986 experiment consisted of six replications with one plant per subplot. In addition, interspecific segregating populations were examined: $\mathrm{BC}_{1}$ [backcrossed $\left.\mathrm{F}_{1} ; \mathrm{M} 82 \times(\mathrm{M} 82 \times \operatorname{Lpen} 716)\right]$ in 1984 (200 plants per treatment), and $F_{2}$ (selfed $F_{1}$ ) in 1985 (350 plants per treatment).

Ion analyses. Plants were harvested at the fruit-ripening stage (at fruit set in the 1985 wild species trial). Samples of each plant were separated into leaves (petioles plus blades) and stems, ovendried, ground, and subjected to ion analyses. Cations were extracted from $200 \mathrm{mg}$ of dry material by wet ashing of the organic matter using $\mathrm{H}_{2} \mathrm{SO}_{4}$ and $\mathrm{H}_{2} \mathrm{O}_{2}$ (Wolf, 1982). Sodium, $\mathrm{K}$ and $\mathrm{Ca}$ concentrations were determined by flame photometer (Corning, M410) and Mg by atomic absorption (Elmer-Perkin, 2380). Chlorine was extracted from $100 \mathrm{mg}$ of dry material by overnight soaking in $50 \mathrm{ml}$ of $0.5 \% \mathrm{HNO}_{3}($ Chapman and Pratt, 1961) and determined by an automatic chloridometer (Buchler-Cotlov) based
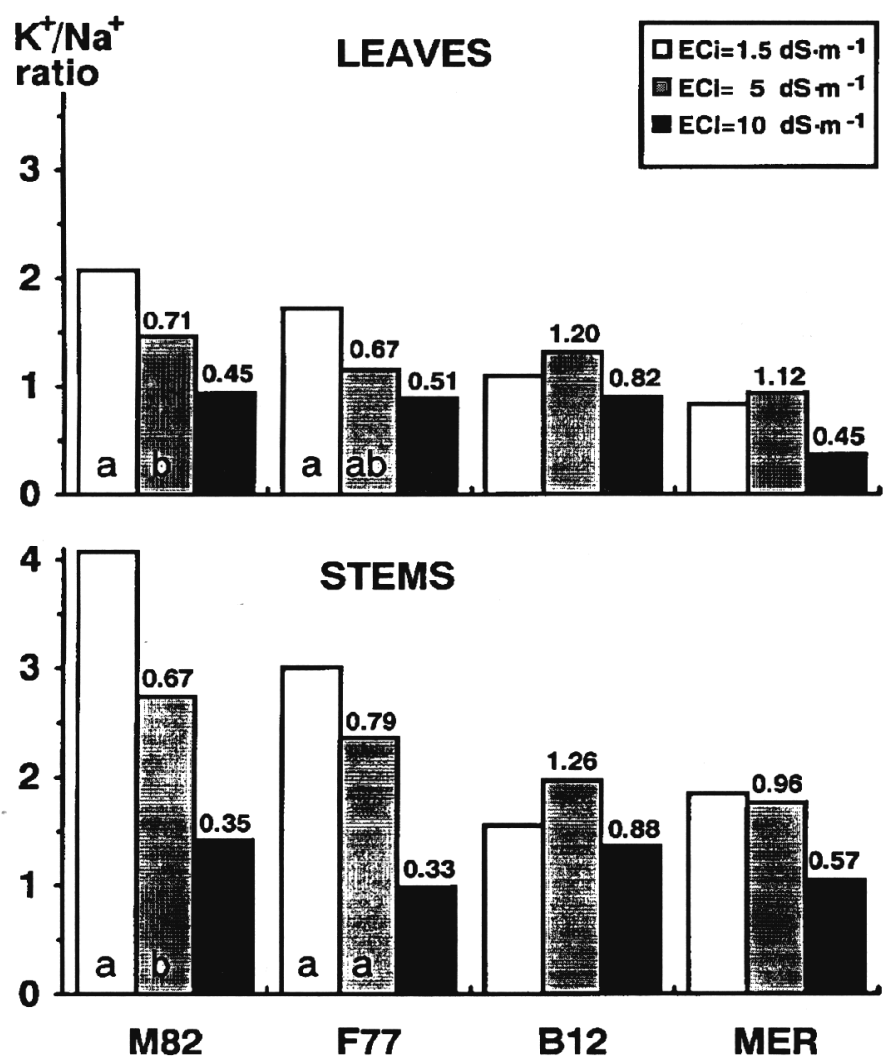

Fig. 1. Effect of salinity on $\mathrm{K}:$ Na ratios in leaves and stems of four tomato cultigens. Numbers above each histogram indicate its value relative to the control. Significant interactions (salinity $\times$ cultigen) were found in both traits. Mean separation between cultigens within each treatment $(\mathrm{a}, \mathrm{b}, \mathrm{c})$ at $P=0.05$. Means having the same letter, or having no letter, are not significantly different. on the titration of silver cations. In both extraction processes a set of 30-40 samples was accompanied by a blank and standard solutions, both of which were measured before and after measurement of the samples. A calibration function was calculated for each set of samples and used to determine the ion concentrations in dry material.

Statistics. Data (excluding the $\mathrm{BC}_{1}$ and $\mathrm{F}_{2}$ populations) were subjected to an analysis of variance and Student-Newman-Keuls's multiple range test at $P=0.05$. Data of the $\mathrm{BC}_{1}$ and $\mathrm{F}_{2}$ interspecific populations were subjected to multiple regression analysis using the stepwise procedure (MAXR method) of the SAS software (Ray, 1982). A regression of the total aboveground dry matter on ion concentrations was performed separately for each population and treatment.

\section{Results and Discussion}

The $\mathrm{K}: \mathrm{Na}$ ratio in leaves (KL : NaL) was usually lower than in stems (KS : NaS) in the tomato cultigens (Fig. 1) and in the wild accessions, mainly due to similar $\mathrm{Na}$ concentrations in both organs and lower $\mathrm{K}$ in leaves relative to stems (data not shown). $\mathrm{KL}: \mathrm{NaL}$ and $\mathrm{KS}: \mathrm{NaS}$ under control conditions were higher in the sensitive cultivars, M82 and F77, than in the tolerant ones, B12 and MER (Fig. 1). In the trials with wild species, $\mathrm{KL}$ : NaL levels in control plants for both the sensitive cultivar M82 and the tolerant $F_{1}$ were higher than those of the tolerant accessions Lpen716 and Lper127831 (Fig. 2).
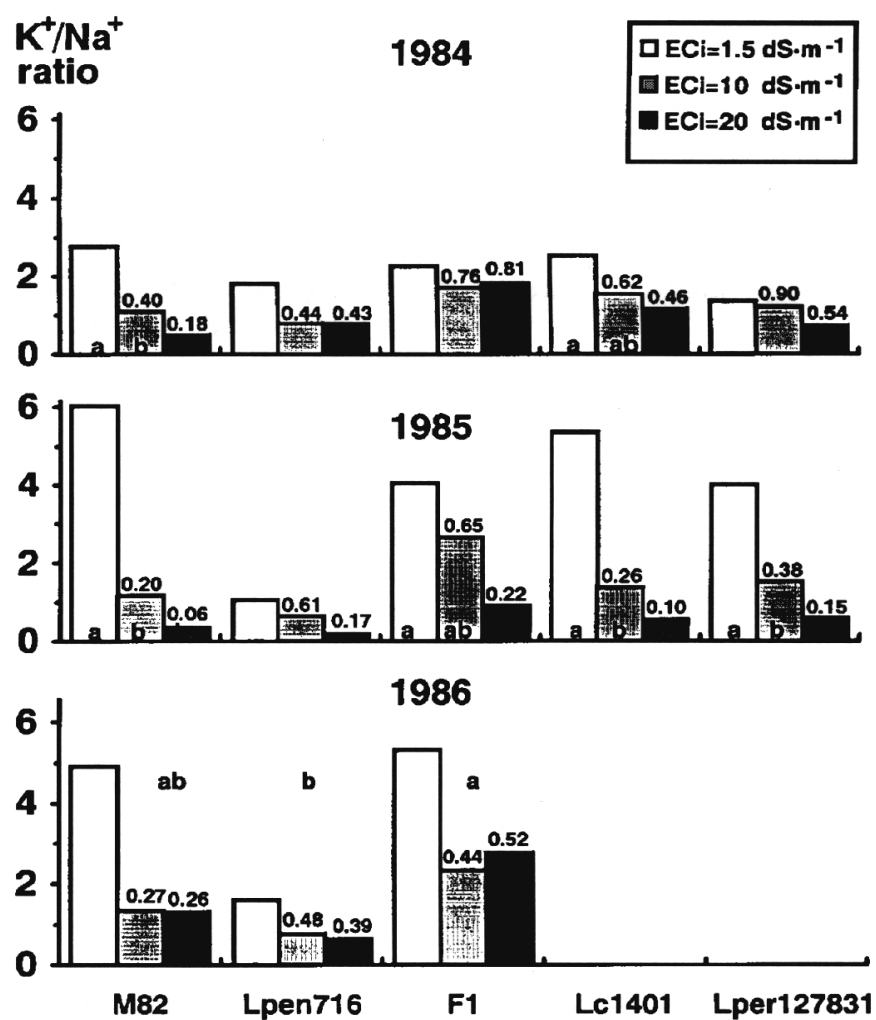

Fig. 2. Effect of salinity on $\mathrm{K}: \mathrm{Na}$ ratios in leaves of Lycopersicon species. Numbers above each histogram indicate its value relative to the control. Significant interactions (salinity $\times$ genotype) were found in 1984 and 1985 and significant effects of salinity and genotypes in 1986. Mean separation between genotypes as a main effect or between genotypes within each treatment $(\mathrm{a}, \mathrm{b})$ at $P=0.05$. Means having the same letter, or having no letter, are not significantly different. 


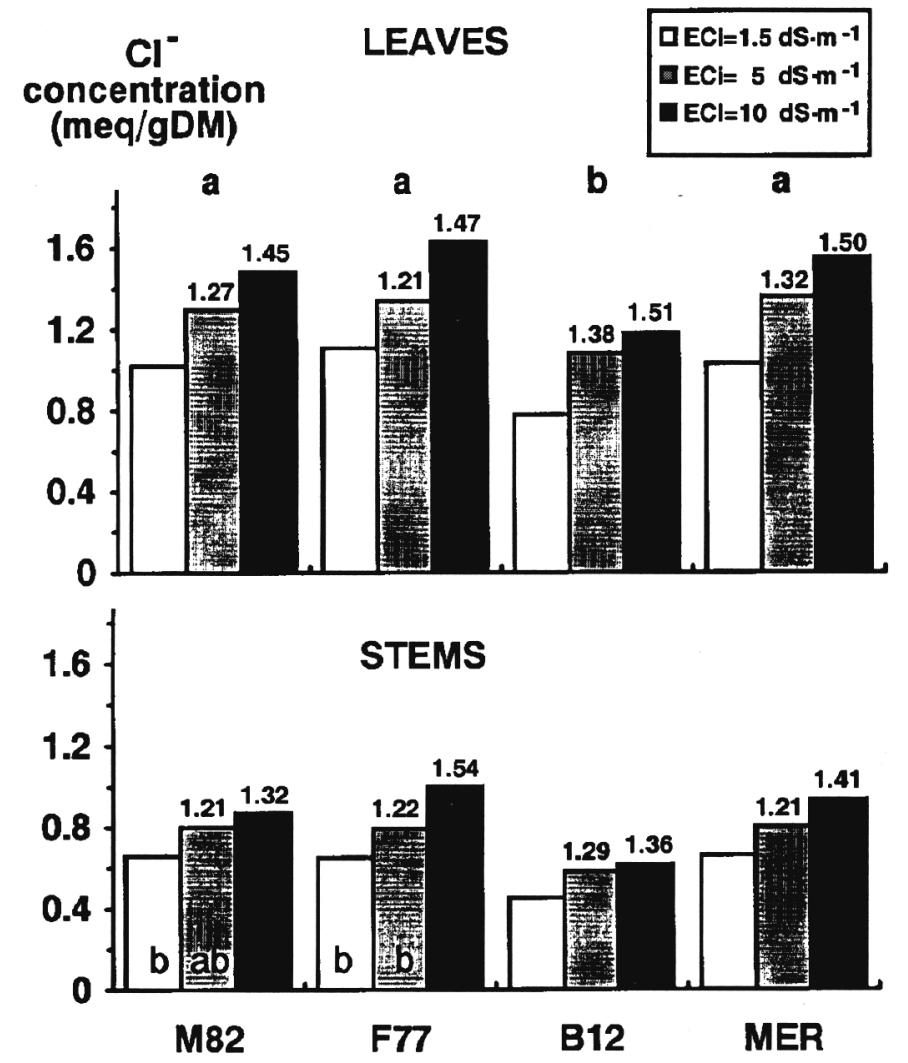

Fig. 3. Effect of salinity on $\mathrm{Cl}$ concentrations in leaves and stems of four tomato cultigens. Numbers above each histogram indicate its value relative to the control. Significant effects of salinity and cultigen were found in leaves and significant interactions (salinity $\times$ cultigen) in stems. Mean separation as in Fig. 2.

The salinity-induced reductions in $\mathrm{K}: \mathrm{Na}$ ratio were most pronounced in the sensitive M82 and F77 cultigens relative to any of the other cultivars, wild species, or $F_{1}$ (Figs. 1 and 2). Salinityinduced changes in $\mathrm{K}: \mathrm{Na}$ ratio of the most sensitive wild acc., Lc1401, were smaller than (1984) or similar (1985) to those for M82, while in the tolerant accessions, Lpen716 and Lper127831, these changes were always smaller (Fig. 2). The highest KL : NaL ratios under saline conditions with the smallest salinity-induced changes were found in the F, which also had the highest salt tolerance. Differences were observed between trials, presumably caused by environmental or management effects. In the 1985 trial, at which the responses to salinity were the most extreme in terms of dry matter (Saranga et al., 1991), the greatest changes in KL : $\mathrm{NaL}$ ratios occurred in all genotypes. The relatively stable KL : $\mathrm{NaL}$ ratio in the tolerant accessions was apparently a result of their ability to minimize changes in both $\mathrm{K}$ and $\mathrm{Na}$ concentrations (data not presented).

The $\mathrm{Cl}$ concentrations in leaves $(\mathrm{ClL})$ or in stems $(\mathrm{ClS})$ were usually similar in all cultigens and were increased to a similar extent by salinity (Fig. 3). Chlorine concentrations in the tomato cultigens did not exhibit any trends that might explain the difference between tolerant and sensitive ones. In the trials with wild species, CIL increased with salinity in 1984 and 1985 but not in 1986 (Fig. 4). The highest levels of CIL were usually found in M82 and the lowest in Lpen716. ClS levels of most accessions were similar and were affected similarly by salinity.

In all the cultigens the CIL : ClS ratio varied from 1.5 to 2.0 over the entire range of salinity treatments. However, in the wild species, CIL, : CIS was unaffected by salinity but it was significantly affected by genotypes (Table 1), being highest in M82 and
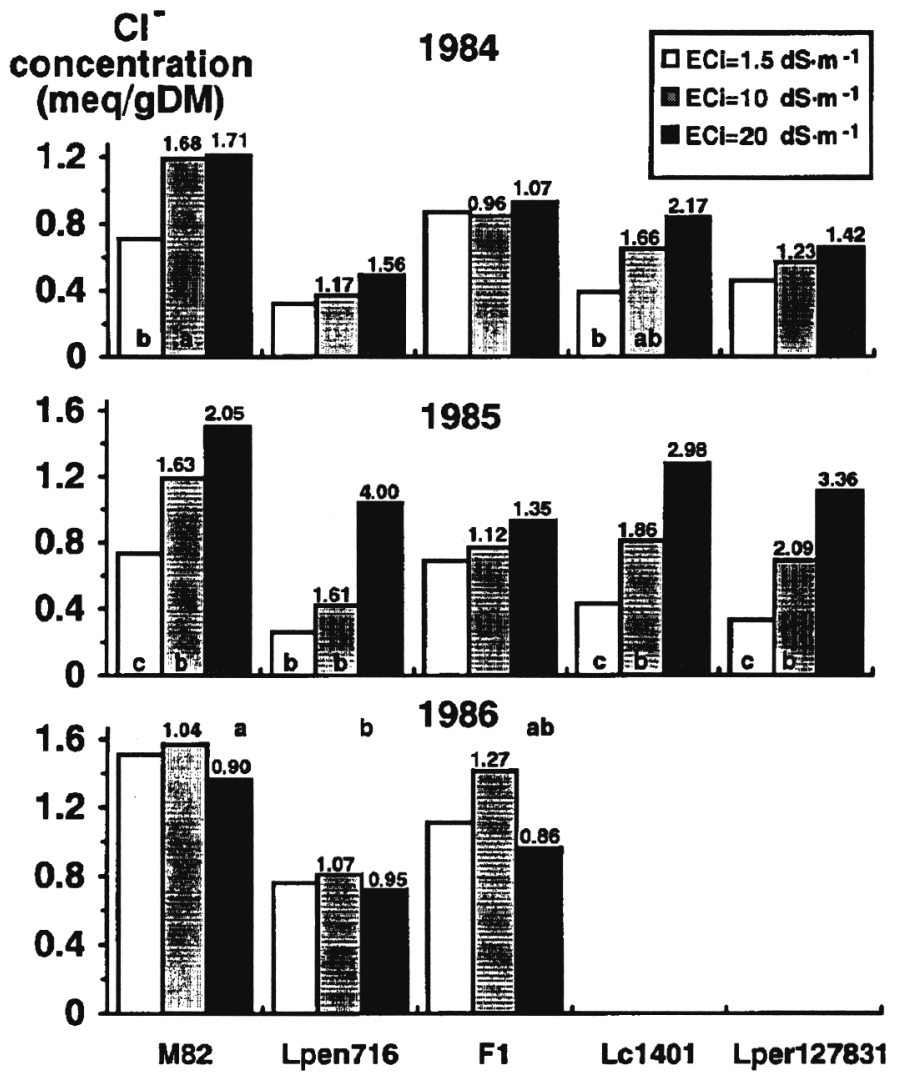

Fig. 4. Effect of salinity on $\mathrm{Cl}$ concentrations in leaves of Lycopersicon species. Numbers above each histogram indicate its value relative to the control. Significant interactions (salinity $\times$ genotype) were found in 1984 and 1985 and significant effect of genotypes in 1986. Mean separation as in Fig. 2.

lowest in Lpen716, although the ratio for M82 did not differ significantly from that of some others in 2 of 3 years. This result may point to the existence of a mechanism that prevents the accumulation of $\mathrm{Cl}$ in leaves of the wild species and the $\mathrm{F}_{1}$ and that may contribute to the salt tolerance exhibited by these genotypes.

The $\mathrm{Ca}$ and $\mathrm{Mg}$ concentrations in the leaves and the stems were not significantly affected by salinity in any of the trials (data not shown). In most cases, significant differences were found between genotypes, but we were unable to detect a consistent trend linking these ions with salt tolerance.

Comparisons between the responses to salinity of various genotypes or species may be misleading on account of differences between these germplasms in growth habit, harvest index, rooting depth, etc. These limitations do not exist in segregating popula-

Table 1. Ratio between concentrations of $\mathrm{Cl}$ in the leaves and stems $(\mathrm{ClL}$ :CIS) of Lycopersicon species. Each value represents the mean of three salinity treatements (salinity effect was not significant).

\begin{tabular}{lccc}
\hline \hline & \multicolumn{3}{c}{ ClL : ClS ratio } \\
\cline { 2 - 4 } Genotype $^{\mathrm{z}}$ & 1984 & 1985 & 1986 \\
\hline M82 & $1.33 \mathrm{a}^{\mathrm{y}}$ & $1.68 \mathrm{a}$ & $2.05 \mathrm{a}$ \\
Lpen716 & $0.59 \mathrm{~b}$ & $0.53 \mathrm{c}$ & $1.13 \mathrm{~b}$ \\
$\mathrm{~F}_{1}$ & $1.23 \mathrm{a}$ & $0.97 \mathrm{~b}$ & $1.88 \mathrm{a}$ \\
Lc1401 & $0.97 \mathrm{a}$ & $1.02 \mathrm{~b}$ & \\
Lper127831 & $1.24 \mathrm{a}$ & $1.31 \mathrm{~b}$ &
\end{tabular}

${ }^{\mathrm{Z}}$ Lycopersicon pennellii (Lpen), L. peruvianum (Lper), L. cheesmanii (Lc).

ya,b,c indicate significant differences at $P=0.05$ between genotypes within each year. 
Table 2. Regression equations associating total dry matter (TD) with ion concentrations in leaves (L) and stems (S) of interspecific segregating populations grown under saline water irrigation $\left(\mathrm{ECi}=20 \mathrm{dS} \cdot \mathrm{m}^{-1}\right)$. Significance levels of coefficients are indicated in brackets.

\begin{tabular}{lccccccc}
\hline \hline & & \multicolumn{7}{c}{ Coefficients of independent variables } & & \\
\cline { 3 - 6 } Population & Intercept & $\mathrm{NaL}$ & $\mathrm{KS}: \mathrm{NaS}$ & $\mathrm{ClL}$ & $\mathrm{ClS}$ & $r^{2}$ & $\mathrm{df}$ \\
\hline $\mathrm{BC}_{1}$ & 1373 & -314 & 51 & -372 & -501 & 0.26 & 168 \\
$\mathrm{~F}_{2}$ & & $(0.022)$ & $(0.008)$ & $(0.0005)$ & $(0.006)$ & & \\
& 115 & 89 & 93 & -58 & -66 & 0.39 & 325 \\
& & $(0.0001)$ & $(0.0001)$ & $(0.0001)$ & $(0.0001)$ & & \\
\hline
\end{tabular}

tions, where each plant represents a random combination of genes from both parental lines. A disadvantage of such a population is that the results can not be related to a control. We, therefore, used total dry matter (TD) rather than the relative dry matter as an indicator of salt tolerance of the segregating populations $\mathrm{BC}$, and $\mathrm{F}_{2}$.

${ }^{2}$ Correlation coefficients $(\mathrm{P})$ between TD and ion concentrations increased with salinity and varied between 0.05 to 0.45 . A regression analysis of TD (dependent variable) on ion concentrations in leaves and stems (independent variables) of $\mathrm{BC}_{1}$ and $\mathrm{F}_{2}$ revealed the highest $r^{2}$ values under the $20 \mathrm{dS} \cdot \mathrm{m}^{-1}$ treatment (Table 2). Lower $r^{2}$ values (0.11 or less) were obtained with the $10 \mathrm{dS} \cdot \mathrm{m}^{-1}$ treatment (not shown). For both $\mathrm{BC}_{1}$ and $\mathrm{F}_{2}$ populations, TD was significantly affected by NaL, KS : NaS, ClL, and CIS. TD was positively correlated with KS : NaS and negatively with CIL and $\mathrm{ClS}$, while $\mathrm{NaL}$ had inconsistent effects on the two populations (Table 2). A high $\mathrm{K}: \mathrm{Na}$ ratio under salinity was associated with small salinity-induced changes in this parameter, as observed in the F, (Fig. 2). Low $\mathrm{Cl}$ concentrations were found in all the tolerant wild accessions and in the $F_{1}$ (Fig. 4). The results of the regression analysis with respect to the effects of the $\mathrm{K}: \mathrm{Na}$ ratio and the $\mathrm{Cl}$ concentration were thus in agreement with the conclusions drawn from the comparison between the various accessions.

Sodium and $\mathrm{Cl}$ accumulation under salinity was previously found in salt tolerant wild Lycopersicon species, while in Le these ions were excluded (Boralin et al., 1991; Phills et al., 1979; Rush and Epstein, 1981; Shannon et al., 1987). Ion accumulation was, therefore, considered as a superior mechanism of salt tolerance in tomato and was suggested as a criterion for evaluating germplasm in breeding programs (Rush and Epstein, 1981). In our study, the average NaL concentrations found under $20 \mathrm{dS} \cdot \mathrm{m}^{-1}$ over the three trials were $0.43,0.73$, and $0.41 \mathrm{meq} / \mathrm{GDM}$, and average KL 0.28 , 0.31 , and $0.59 \mathrm{meq} / \mathrm{GDM}$ for M82, Lpen716, and $\mathrm{F}_{1}$, respectively. Sodium plus $\mathrm{K}$ in Lpen 716 and $\mathrm{F}_{1}$ were similar and higher than in M82. Of these two ions, Na played an important role in the osmotic regulation of Lpen716, while in the $\mathrm{F}_{1} \mathrm{~K}$ had this role. These results suggest that ion accumulation and also the ability to regulate the $\mathrm{K}$ : Na ratio (possibly resulting in a more favorable internal environment) contributed to the high salt tolerance exhibited by $\mathrm{F}_{1}$ plants. Regulation of $\mathrm{Na}$ concentration and $\mathrm{K}: \mathrm{Na}$ ratio, in association with salt tolerance, were reported by Sacher et al. (1983) and Hashim et al. (1988). Restriction of $\mathrm{Cl}$ accumulation was also found in the wild species and $\mathrm{F}_{1}$ but not in Le, contrary to previous reports. Transfer of this character from wild germplasm to Le may further improve the salt tolerance of the tomato.
Evaluation of ion contents is a labor intensive process, especially when it has to be done under control and saline conditions to estimate relative values. Therefore, determination of $\mathrm{K}: \mathrm{Na}$ ratio and $\mathrm{Cl}$ concentrations has limited value in a breeding program. In such a case, the use of genetic markers, such as isozymes or RFLPs, may be a more efficient and useful method.

\section{Literature Cited}

Besford, R.T. 1978. Effect of replacing nutrient potassium by sodium on uptake and distribution of sodium in tomato plants. Plant \& Soil 50:399409.

Boralin, M.C., F.G. Fernandez, V. Cruz, and J. Cuartero. 1991. Salinity tolerance in four wild tomato species using vegetative yield-salinity response curves. J. Amer. Soc. Hort. Sci. 116:286-290.

Chapman, H.D. and P.F. Pratt. 1961. Methods of analysis for soils, plants, and waters, p. 309. Univ. of California, Div. Agr. Sci., Riverside.

Cheesenam, J.M. 1988. Mechanisms of salinity tolerance in plants. Plant Physiol. 87:547-550.

Flowers, T.J., P.F. Troke, and A.R. Yeo. 1977. The mechanism of salt tolerance in halophytes. Annu. Rev. Plant Physiol. 28:89-121.

Greenway, H. and R. Munns. 1980. Mechanisms of salt tolerance in nonhalophytes. Annu. Rev. Plant Physiol. 31:149-190.

Hashim, M.M., A.S. El-Beltagy, and R.A. Jones. 1988. Salt tolerance in Lycopersicon esculentum. II. Ion accumulation patterns. Egyptian J. Hort. 15:97-106.

Lerner, H.R. 1985. Adaptation to salinity at the plant cell level. Plant \& Soil 89:3-14.

Phills, B.R., N.H. Peck, G.E. MacDonald, and R.W. Robinson. 1979. Differential response of Lycopersicon and Solanum species to salinity. J. Amer. Soc. Hort. Sci. 104:349-352.

Ray, A.A. (ed.). 1982. SAS user's guide: Statistics, p 584. SAS Inst., Cary, N.C.

Rush, D.W. and E. Epstein. 1981. Comparative studies on the sodium, potassium, and chloride relations of a wild halophytic and a domestic salt-sensitive tomato species. Plant Physiol. 68:1308-1313.

Sacher, R.F., R.C. Staples, and R.W. Robinson. 1983. Ion regulation and response of tomato to sodium chloride: A homeostatic system. J. Amer. Soc. Hort. Sci. 108:566-569.

Saranga, Y., D. Zamir, A. Marani, and J. Rudich. 1991. Breeding tomato for salt tolerance: Field evaluation of Lycopersicon germplasm for yield and dry matter production. J. Amer. Soc. Hort. Sci. 116:1067-1071.

Shannon, M.C., J.W. Gronwald, and M. Tal. 1987. Effects of salinity on growth and accumulation of organic and inorganic ions in cultivated and wild tomato species. J. Amer. Soc. Hort. Sci. 112:416-423.

Wolf, B. 1982. A comprehensive system of leaf analyses and its use for diagnosing crop nutrient status. Commun. Soil Sci. Plant Anal. 13: 10351059 . 